\title{
Culture and Media
}

\author{
Kawalpreet $\operatorname{Kaur}^{1 *}$
}

\section{ABSTRACT}

In the present study a comparison between movies whose remake has been made in a different cultural context was selected. The movie selected for the purpose was Hollywood movie; Harry met sally and its Bollywood remake, Hum Tum. The cultural differences and similarities between the two movies were analysed through theory based content analysis. The differences were found in terms were in terms of values, norms, attitudes, situations, language, art, and literature, marriage, and relationships and similarities were found in context of importance the culture place on friends. The differences can be attributed to the reason that Bollywood filmmakers operate as cultural mediators and evaluates the appropriateness of a film according to their perception of the audience, and this Indianization continues to make a movie culturally adaptable. Every cinema reflects the culture of which it belongs, and a nation's cultural conventions, traditions, and expectations will affect the remake in significant ways. Thus, a movie is a common and important form of cultural expression.

Keywords: Media, Cultural differences, Bollywood, Hollywood, Remix

Media is the collective communication outlets or tools that are used to store and deliver information or data. It is either associated with communication media or the specialized communication businesses such as: print media and the press, photography, advertising, cinema, broadcasting (radio and television) and publishing. Whereas the mass media is a diversified collection of media technologies that reach a large audience via mass communication. The technologies through which this communication takes place include a variety of outlets (Adorno, 1991)

Broadcast media transmit information electronically, via such media as film, radio, recorded music, or television. Digital media comprises both Internet and mobile mass communication. Internet media comprise such services as email, social media sites, websites, and Internet-based radio and television. Outdoor media transmit information via such media as AR advertising; billboards; blimps; flying billboards; placards or kiosks placed inside and outside of buses,

\footnotetext{
${ }^{1}$ Psychology, IP college for women, Delhi university, India *Responding Author

(C) 2016 I K Kaur; licensee IJIP. This is an Open Access Research distributed under the terms of the Creative Commons Attribution License (http://creativecommons.org/licenses/by/2.0), which permits unrestricted use, distribution, and reproduction in any Medium, provided the original work is properly cited.
} 


\section{Culture and Media}

commercial buildings, shops, sports stadiums, subway cars, or trains; signs; or skywriting. Print media transmit information via physical objects, such as books, comics, magazines, newspapers, or pamphlets. Event organizing and public speaking can also be considered forms of mass media (Manohar, 2011)

\section{PSYCHOLOGY AND MEDIA}

Despite the disappearance of media psychologists from psychology over the last century, the influence of the media on everyday behaviour is so insidious that it has been impossible to dispel it completely. Indeed, its effect on social change has been so rapid that references to media phenomena now abound in psychological research, and their status as media phenomena is often completely ignored (Giles, 2003). Every decade in the last 50 years has seen major developments in mass communications and media.

According to Luskin, (2008), Media psychology is the branch of psychology that focuses on the relationships between human behaviour and the media. This branch is a relatively new field of study because of advancement in technology. Media psychology flows from the application of theories in psychology to media. Specifically included are the use of pictures, graphics and sound in all forms of new communications technology. Media psychology is the interface between media and the human response. Implications sometimes involve complex and unique legal and ethical challenges. One generally learns psychology one theory at a time and begins to combine and apply theories based on increasing insight. Media Psychology represents the convergence of psychology applied to media, technology, communication, and is an art and science.

Media psychology is concerned with a wide swath of human behavior, especially so in an increasingly media-dominated society. Media Psychology analyzes how media cover great or tragic moments that come to define a culture, such as the first walk on the moon or the last moments of a fallen president (Stuart Fischoff,2005)

More specifically, media psychology is concerned with the inter- and intra-personal psychological dimensions underlying the impact and use of any medium of communication, irrespective of the nature of the subject matter being communicated. In other words, media psychology is concerned with the social and psychological parameters of communications between people (or people and other organisms) that are mediated by some technology or conduit other than simply air. Disciplines are as much defined by what they exclude as what they embrace; by what they are not as much as what they are.

Media psychology bridges the gap by helping us better understand some of the implications of technological change. Researchers hypothesize, operationalize, and quantify the impact of media. Research in media psychology, however, is difficult; complicated by the fact that it's hard to realistically measure things that are so integrated in the fabric of everyday life. It's 


\section{Culture and Media}

extraordinarily tricky to separate out confounding variables in our complex world. Today, we are media consumers, producers and distributors and our choices have direct impact on what others produce for us to see.

\section{MEDIA AND CULTURE}

Culture is set of patterns of human activity within a community or social group and the symbolic structures that give such activity significance. Customs, laws, dress, architectural style, social standards, religious beliefs, and traditions are all examples of cultural elements. Cambridge English Dictionary states that culture is, the way of life, especially the general customs and beliefs, of a particular group of people at a particular time. Culture is the complex whole that consists of everything we think and do and have as members of society.(Bierstedt, 2003).

Culture is the total content of the physio-social, bio-social and psycho-social universe man has produced and the socially created mechanisms through which these social product operate (Anderson and Parker, 2000). Mlinowlski defines culture as the handiwork of man and the medium through which he achieves his ends.

\section{Following are the functions of culture:}

\section{Culture Defines Situations:}

Each culture has many subtle cues which define each situation. It reveals whether one should prepare to fight, run, laugh or make love. For example, suppose someone approaches you with right hand outstretched at waist level. What does this mean? That he wishes to shake hands in friendly greeting is perfectly obvious - obvious, that is to anyone familiar with our culture.

But in another place or time the outstretched hand might mean hostility or warning. One does not know what to do in a situation until he has defined the situation. Each society has its insults and fighting words. The cues (hints) which define situations appear in infinite variety. A person who moves from one society into another will spend many years misreading the cues. For example, laughing at the wrong places.

\section{Culture defines Attitudes, Values and Goals:}

Each person learns in his culture what is good, true, and beautiful. Attitudes, values and goals are defined by the culture. While the individual normally learns them as unconsciously as he learns the language. Attitudes are tendencies to feel and act in certain ways. Values are measures of goodness or desirability, for example, we value private property, (representative) Government and many other things and experience.

Goals are those attainments which our values define as worthy, (e.g.) winning the race, gaining the affections of a particular girl, or becoming president of the firm. By approving certain goals 


\section{Culture and Media}

and ridiculing others, the culture channels individual ambitions. In these ways culture determines the goals of life.

\section{Culture defines Myths, Legends, and the Supernatural:}

Myths and legends are important part of every culture. They may inspire, reinforce effort and sacrifice and bring comfort in bereavement. Whether they are true is sociologically unimportant. Ghosts are real to people who believe in them and who act upon this belief. We cannot understand the behaviour of any group without knowing something of the myths, legends, and supernatural beliefs they hold. Myths and legends are powerful forces in a group’s behaviour.

Culture also provides the individual with a ready-made view of the universe. The nature of divine power and the important moral issues are defined by the culture. The individual does not have to select, but is trained in a Christian, Buddhist, Hindu, Muslim or some other religious tradition. This tradition gives answers for the major (things imponderable) of life, and fortuities the individual to meet life's crises.

\section{Culture provides Behavior Patterns:}

If men use culture to advance their purposes, it seems clear also that a culture imposes limits on human and activities. The need for order calls forth another function of culture that of so directing behavior that disorderly behavior is restricted and orderly behavior is promoted. A society without rules or norms to define right and wrong behavior would be very much like a heavily travelled street without traffic signs or any understood rules for meeting and passing vehicles. Chaos would be the result in either case. Social order cannot rest on the assumption that men will spontaneously behave in ways conducive to social harmony.

The relationship between society, culture and personality is stressed by Ralph Linton: “A society is organized group of individuals. A culture is an organized group of learned responses. The individual is living organism capable of independent thought, feeling and action, but with his independence limited and all his resources profoundly modified by contact with the society and culture in which he develops. A society cannot exist apart from culture. A Society is always made of persons and their groupings. People carry and transmit culture, but they are not culture. No culture can exists except as it is embodied in a society of man; no society can operate without, cultural directives. Like matter and energy, like mind and body, they are interdependent and interacting yet express different aspects of the human situation.

Mass media is communication-whether written, broadcast, or spoken - that reaches a large audience. This includes television, radio, advertising, movies, the Internet, newspapers, magazines, and so forth. Mass media is a significant force in modern culture, particularly in America. Sociologists refer to this as a mediated culture where media reflects and creates the culture. Communities and individuals are bombarded constantly with messages from a multitude 


\section{Culture and Media}

of sources including TV, billboards, and magazines, to name a few. These messages promote not only products, but moods, attitudes, and a sense of what is and is not important. Mass media makes possible the concept of celebrity: without the ability of movies, magazines, and news media to reach across thousands of miles, people could not become famous. Media is influenced by culture as much as the programming or stories that they are enveloped within. Media cannot escape the cultural influence. Culture provides media with sources for content. All contents are derived from culture including entertainment, news and advertisement. Media and culture are in correlation: Communication media are hand down values and norms of culture, culture hands down media contents (discourse). By the heavy use and great value which communication media are taking nowadays, culture and media can't be separated from each other. Our languages are our media. Our media are our metaphors. Our metaphors manage the contents of our culture.

The influence of culture on media can be seen in context of movies as well. Filmmakers have grown accustomed to tailoring their movies to foreign audiences even as they are being shot. Nudity is much more acceptable for general audiences in Europe than in the United States. Directors making films with nudity and strong sexual content often shoot two (or more) versions of some scenes. More extended and explicit scenes are edited into European versions, while shorter and less explicit scenes are used in the U.S. version. But even kids' movies may be altered to meet the unique needs of each market. The first Harry Potter book, for example, was titled The Philosopher's Stone in England but renamed The Sorcerer's Stone in the United States because the publisher thought the original title sounded a bit bland. When the movie was made, the titles were similarly customized for the two markets. And, because holidays vary from country to country, studios normally adjust a movie's opening date to fit local circumstances.

While it's tricky to predict which movies will work in specific foreign markets, some experts do think preference patterns exist. U.S. movies about racial or diversity issues (such as Crash) do not play well in foreign markets. Animated comedies like Toy Story, Shrek, and Chicken Little are almost universal in their appeal, but comedies based on social patterns or stereotypes may not travel as well. For instance, Wedding Crashers earned \$209 million in the United States but only $\$ 75$ million overseas. Action adventures with Tom Cruise and martial arts flicks starring Jackie Chan also do well in foreign countries, no doubt in part because the viewer does not have to have a firm grasp of the subtleties of the English language to follow the plot. Yet there are exceptions to this rule. I Am Sam, focused on the parental rights of the mentally challenged, did extremely well in markets like Japan and Korea—outselling action flicks like The Bourne Identitybecause of its appeal to Asian females.

Cultural imperialism is the cultural aspects of imperialism. Imperialism, here, is referring to the creation and maintenance of unequal relationships between civilizations favouring the more powerful civilization. Therefore, it is the practice of promoting and imposing a culture, usually of politically powerful nations over less potent societies. It is the cultural hegemony of those 


\section{Culture and Media}

industrialized or economically influential countries, which determine general cultural values and standardize civilizations throughout the world. Many scholars employ the term, especially those in the fields of history, cultural studies, and postcolonial theory. The term is usually used in a pejorative sense, often in conjunction with a call to reject such influence.

\section{Movie as a reflection of culture:}

Movies have long been a mirror of our culture, reflecting the attitudes, morals and fashions of the times. The relationship between movies and culture involves a complicated dynamic; while movies certainly influence the mass culture that consumes them, they are also an integral part of that culture, a product of it, and therefore a reflection of prevailing concerns, attitudes, and beliefs. In considering the relationship between film and culture, it is important to keep in mind that, while certain ideologies may be prevalent in a given era, not only is American culture as diverse as the populations that form it, but it is also constantly changing from one period to the next. Mainstream films produced in the late 1940s and into the 1950s, for example, reflected the conservatism that dominated the sociopolitical arenas of the time. However, by the 1960s, a reactionary youth culture began to emerge in opposition to the dominant institutions, and these anti-establishment views soon found their way onto screen — a far cry from the attitudes most commonly represented only a few years earlier.

In one sense, movies could be characterized as storytellers. Not only do Hollywood films reflect certain commonly held attitudes and beliefs about what it means to be American, but they also portray contemporary trends, issues, and events, serving as records of the eras in which they were produced. Consider, for example, films about the September 11, 2001, terrorist attacks: Fahrenheit 9/11, World Trade Center, United 93, and others. These films grew out of a seminal event of the time, one that preoccupied the consciousness of Americans for years after it occurred.

\section{Myths and Traditions}

American identity in mass society is built around certain commonly held beliefs, or myths about shared experiences and these American myths are often disseminated through or reinforced by film. One example of a popular American myth, one that dates back to the writings of Thomas Jefferson and other founders, is an emphasis on individualism-a celebration of the common man or woman as a hero or reformer. With the rise of mass culture, the myth of the individual became increasingly appealing because it provided people with a sense of autonomy and individuality in the face of an increasingly homogenized culture. The hero myth finds embodiment in the Western, a film genre that was popular from the silent era through the 1960s, in which the lone cowboy, a semi nomadic wanderer makes his way in a lawless, and often dangerous, frontier. An example is 1952's High Noon. From 1926 until 1967, Westerns accounted for nearly a quarter of all films produced. In other films, like Frank Capra's 1946 movie It's a Wonderful Life, the individual triumphs by standing up to injustice, reinforcing the 


\section{Culture and Media}

belief that one person can make a difference in the world. And in more recent films, hero figures such as Indiana Jones, Luke Skywalker (Star Wars), and Neo (The Matrix) have continued to emphasize individualism.

\section{Social Issues in Film}

As D. W. Griffith recognized nearly a century ago, film has enormous power as a medium to influence public opinion. Ever since Griffith's The Birth of a Nations parked strong public reactions in 1915, filmmakers have been producing movies that address social issues, sometimes subtly, and sometimes very directly. More recently, films like Hotel Rwanda (2004), about the 1994 Rwandan genocide, or The Kite Runner (2007), a story that takes place in the midst of a war-torn Afghanistan, have captured audience imaginations by telling stories that raise social awareness about world events. And a number of documentary films directed at social issues have had a strong influence on cultural attitudes and have brought about significant change.

\section{Remakes and cross-cultural remakes}

Cross-cultural exchanges have developed throughout the world for centuries. One aspect of cross-cultural exchange is the film remake - a film based on another film. The cinematic remaking of other films has a long history and cinemas around the world have continually remade other nations' films (Forrest and Koos, 2002). Every cinema reflects the culture of which it belongs, and a nation's cultural conventions, traditions, and expectations will affect the remake in significant ways. The remake is a common and important form of cultural borrowing and expression in a globalized world. According to Forrest and Koos, this is especially true in Hollywood where filmmakers have continually remade American films and "Americanized" foreign films. The remake is an important part of cinema and culture as it can give insight into aspects such as cultural differences, cinematic style, race and gender perceptions, and audience expectations. The cross-cultural remake is not only an American phenomenon. The national cinema of India, popularly known as Bollywood, has also been remaking and "Indianizing" Hollywood films for centuries.

A general definition of the film remake can be found in Forrest and Koos (2002), who describe the remake as a film derived from a previously made film. In addition, a remake is a film which has intertextual connections with an earlier film. The term is often used in reference to a film which uses an earlier film as the main source material, but many remakes will also make significant character, plot, and theme changes from the original. While intertextually related to an earlier film, the remake will therefore "differentiate itself in terms of variation and revision of different aspects.”

Remakes not only include Hollywood remaking, but remakes across culture and media. Crosscultural remakes are also found in many other countries around the world and Hollywood narratives have increasingly become the basis for foreign films, where filmmakers make over 


\section{Culture and Media}

U.S films in their own specific cultural and cinematic traditions. For Horton, this can be seen as an attempt to feel connected to a world film community and a way to tell the same story but with a different meaning, where the otherness of this meaning is what sets it apart. Horton and McDougal want to extend the definition of remakes to include films that take inspiration from, or only allude to, previous films, meaning cross-cultural remakes where cultural traditions, language, and narrative may differ greatly. McDougal uses the example of Time of the Gypsies (Kusturica, 1988), a remake that has placed the American Italian The Godfather (Coppola, 1972) into a gypsy cultural setting. There are therefore great possibilities for big changes when films are remade across culture, where the film is made over to reflect both personal and cultural interests.

This makeover does not suggest a direct adaptation, but a range of similarities as a remake includes a self-conscious balancing act between the familiar and the new. It can involve making significant changes to show the culture and national film traditions, with multiple cultural differences in terms of setting, themes, characters, gender, family, religion, and ending. For Forrest and Koos, cross-cultural film remaking is about cultural translation, translating the other, the foreign cultural references, into the known. It can be compared to free translations, being generally faithful to the spirit of the text, while adapting it to the aesthetic, moral, and cultural concerns of the target culture. A remake does not always show that it is a remake or that it has taken inspiration from a previous source. The main issue lies in the translation process, as culturally specific elements disappear or change in the remake while other specific parts are kept, and own culturally specific parts are added.

Research on cross-cultural remakes in India is limited. Still, there are a few theorists on this subject who draw upon previous theory, by accepting their usefulness but also seeing their limitations. Tejaswini Ganti explains how remakes are often labeled as 'copies' in India, and that many filmmakers see nothing wrong with copying film plots from Hollywood films, which have been sources of inspiration for decades. Ganti further explains how Indian filmmakers are searching out and "Indianizing" suitable Hollywood films to make them appropriate for India's diverse cinema audience. Only certain films can be remade and thereby Indianized as they must contain certain elements in terms of plots, characterizations, thematic elements, melodrama, and moral values which are suitable for Bollywood and India, and which will be approved by the Indian viewers. The audience is very important in India, and they must be able to identify with the film they are watching. The Indian audience has had difficulty relating to Hollywood films in the past, so Hollywood has not been seen as a threat or as a competitive force, only as a source

for usable stories. Filmmakers therefore choose and alter suitable Hollywood films in terms of narrative, dramatic, and aesthetic choices made by what they believe the audience will accept. After choosing a suitable film, the filmmaker can then add specific Indian elements to its plot and narrative.

(C) The International Journal of Indian Psychology, ISSN 2348-5396 (e)| ISSN: 2349-3429 (p) | 200 


\section{Culture and Media}

Indianizing a film means adding the specific formula, film language, and cinematic elements of Bollywood. This process of Indianization generates culture effects, signifying the production of Indianess - against the other, the West, and Hollywood. For Ganti, this includes adding three central Hindi film "ingredients". The first of these includes "adding emotion." Hollywood is often seen as 'dry', but adding great and powerful emotions such as love, hate, revenge, and morals will make it more suitable in India. Another ingredient is "expanding the narrative." This is done by adding a pre-story, subplots, parallel stories, flashbacks, and adding twists thereby developing complexity in the narrative. Hollywood is often more clear and has a straight forward narrative, while the audience in India on the other hand, expects to see 'everything' in one Bollywood film, including comedy, romance, drama, and action. The third basic ingredient is of course the "song and dance" sequences, as almost every Bollywood film must include at least 68 songs. These three basic ingredients thereby give greater narrative complexity and specificity to the film remake which necessarily have to be included in order for the film to be acceptable and relatable for the vast Indian and global audience and their expectations of Bollywood films. Ganti argues that Bollywood filmmakers operate as cultural mediators, evaluating the appropriateness of a film according to their perception of the audience, and this Indianization continues to be a conservative process as it stays the same and keeps the risks low.

Some of the many films that have been remade and thereby Indianized, are Dead Poets Society (Weir, 1989) into Mohabbatein (Chopra, 2000), Three Men and a Baby (1987) into HeyyBabyy (Khan, 2007), and When Harry Met Sally (Reiner, 1989) into Hum Tum (Kohli, 2004). Common for all these films is the adding of content, Indian morality, stronger emotions - in particular love, and the song and dance sequences, making them suitable for India, Bollywood, and its audience.

When dealing with cross-cultural remakes one is dealing with cultural adaptation, as one can analyse film remakes not only in their textual and structural specificity, but in a wider cultural context. The cultural analysis includes the filmic and cultural element changes accompanying this process of remaking from the American culture seen through Hollywood, with the culture of India presented through Bollywood cinema. The changes include adjusting the story to fit with the classical rules of the genre story-telling worked out in America, and the cinematic formula of Hindi Cinema.

The United States is a young, but powerful and global nation. It is also one of the most culturally diverse countries in the world, with a wide variety of peoples, religions, and beliefs with an emphasis on the individual. Hollywood is not able to reflect this but it remains the center of America's popular culture, just as Bollywood in India. In American Film and Society since 1945, Leonard Quart and Albert Auster argue that film is a powerful and significant art form, and it can sometimes convey and imitate society, and capture and reveal something of the reality, the dreams, and the social issues that confront American society. Although social realism may not be

(C) The International Journal of Indian Psychology, ISSN 2348-5396 (e)| ISSN: 2349-3429 (p) | 201 


\section{Culture and Media}

an important aesthetic in Hollywood, films have resonance for audiences because they can reinforce existing public fantasies and feelings. Films reach a mass audience with their cultural and social meaning. They were and are also often bound by formulas or institutional forces such as censorship and the star system which will affect the film, and the relationship between them and society therefore remains complex. Still, they argue that it is the underlying cultural patterns, not the individual artist that creates meaning in a film. Therefore it can be said that mainstream Hollywood film will reflect, and to a certain degree reveal and imitate, parts of U.S reality and also provide with great fantasy and adventure. It cannot reflect the variety and complexity of the United States and its culture, but it is still valued by its national and global audience.

On the other side of the globe, we find India and Bollywood. Here, Hindi commercial cinema has become part of everyday Indian life. Bollywood films do to some degree reflect the reality of the growing, urban middle class in India and in the Diaspora, but this is far removed from the rest of India. India is a diverse, multi-ethnic country with 4500 years of cultural history and a vast population of 1.2 billion people. The culture is therefore complex and varied, even more so than in the United States, with its diverse peoples, cultures, languages, religions, and traditions. India has also been heavily influenced by the West as a British colony and today, it has become more westernized by the growth of globalization and Americanization. The middle-class and urban life-style in India resembles in many ways that of the West, while rural life stays the same. While the U.S is centered on the individual, India is centered on the collective. Therefore, family is the most important social unit, where people live under a clear order of social precedence based on gender and age, where the senior male is the family head. Indian culture is therefore patriarchal, where female discrimination and arranged marriages are common. The high versus low culture that we find in Edensor and Hall is though not applicable in India, as films are cultural forms that are both seen as entertainment and art. Indian music, dance, and cinema play an integral role in the lives of the Indian population, which is very much reflected in film. The Hindi film caters to these denominators, and helps to create a homogenized culture on screen. Film is therefore an important part of culture, and will often imitate society on many different levels. They reflect and take up the issues on national identity, gender, caste, class, and wealth, as well as unpack the fantasy, hopes, and fears of the nation.

Tradition and westernization goes hand in hand in culture and in cinema. In this line between traditional culture and modernity, the 'old' hangs on the 'new' as change and continuity are parallel historical processes. Bollywood has is many ways a monopoly on Indian cultural life. In an ever changing society, many feel that the trip to the cinema provides them with an escape from reality. Bollywood films are therefore in many ways divorced from Indian society realism, though they still express cultural norms and Indian values. For many, the escapist entertainment

of Bollywood films offers an escape from poverty to a dream world, forgetting their every-day life, while also showing important parts of life such as family, love, conflicts, and the battle over tradition versus modernity. Bollywood therefore affects Indian culture and the audience in 


\section{Culture and Media}

profound ways even today, and shows a constructed Indianess rooted in the reality and fantasies of India where the Masala film musical acts as a cultural unifier.

\section{INDIANIZATION STRATEGIES}

The re-working of foreign material for Hindi films has been approached by film and media scholars in mainly three ways. There are case studies of individual films that 'Indianize' foreign texts, such as Mazy Donaldson-Evans's article about Ketan Metha's Madame Bovary adaptation Maya Memsaab (1992), or Michael Lawrence's essay about Do Phool (Abdul Rashid Kardar, 1958), a film adaptation of Johanna Spyri's children's novel Heidi. A second strategy has emerged in the most recent texts about the phenomenon. They approach the Bollywood remake in the context of globalized cinema, identifying and analysing concrete textual changes but placing them in a larger context of transculturality. Iain Robert Smith, for example, does not try to identify national cultural reasons for the textual changes in Hindi remakes but examines Zinda, the unofficial Hindi version of South Korean film Oldboy, in terms of cultural exchange in the context of global media and geo-cultural flows (2013). He regards the film "less as an attempt to 'Indianize' the source text than as an attempt to create a Hollywood film which engages with the common stylistic and narrative tropes of the global horror genre" (2013) in order to reach beyond India.

\section{Bollywood remakes and the notion of transcultural remakes}

Every year more than 800 movies are produced in India and exported to China, East Asia and the whole Islamic world from Morocco to Indonesia. In recent years, some Indian films have even been shown in the cinematographic diaspora of Europe, Australia and the USA. The great success of Indian cinema can be traced back to an affinity for opulent dancing scenes, but also to the rigid censorship: kisses on the mouth, explicit sexuality and nudity are taboo. However, most notably, in the majority of cases the movies have a happy end. Up to now Western film critics have concentrated on the few socio-critical works of Indian directors, for instance the films Salaam Bombay (1988) or the current Monsoon Wedding by Mira Nair. This last film has been considered as the staging of the Indian conflict between tradition and modernity in the microcosm of a wedding party (Raweh 2002). In my opinion, popular Indian movies reflect social conflicts between tradition and modernity just as much as the above mentioned works, and furthermore they often include a strong utopian notion - the vision of conciliation and harmony between the antagonistic powers: Bollywood after all is not just a dream factory that belts out trashy material in the fashion of assembly line production. The potpourri despite itself, offers a glimpse of India's values, traditions, and contemporary events often in a unique formulaic package (Kahn \&Debroy 2002, Kazmi 1999).

Remakes have always remained a fascinating subject among film critics and scholars. While few other art forms maintain their creative vigour and refreshing fascination when remade, film stands as the most popular expressive art form that creates original works through remakes and 


\section{Culture and Media}

adaptations. Such resilience and malleability are even more characteristic in trans-cultural film remakes, where filmic texts transcend social, cultural, geo-political, and linguistic borders. Film scholars have been so confounded and intrigued by the combination of repetition and innovation in the diptych of the original film and its transcultural remake that they habitually resort to figurative language and metaphors in their analyses of such pairs. For example, AnatZanger, in his Film Remakes as Ritual and Disguise: From Carmen to Ripley (2007), touches upon the potential symbiosis between original and remake. Treating film remakes as products of a society's survival mechanism that both preserves and reconditions its own cultural metanarrative, Zanger goes beyond apparent differences between originals and remakes to reveal a common typology along the vertical historical axis of cultural reproduction.

Cultural, religious and social identities have always been interrelated and leading topics in Indian cinema. From the start, Indian filmmakers realized the possibilities of voicing contemporary social and political concerns: Dhiren Ganguly attacked the Western way of life in his film Bilet Pherat aka England Returned of 1921 (Kahn \& Debroy 2002). Raj Kapoor's film Shri 420 of 1955 became famous for illustrating rising social and cultural conflicts in the early process of India's postcolonial modern times (Parasher 2002). Topics of identity and even fundamentalism in Indian movies have repeatedly been considered by Indian scholars (Chakravarty 1993, Mishra 2002), while the question of Indian identity in the diaspora confronted with Western modernity is a rather new perspective (Mishra 2002). Evidently Hindu rituals play a central role within the cinematic presentation of conflicts in recent films. Thus, focusing on rituals in popular Indian movies is not only a question of an unexplored issue in film analysis, but rather a highly significant aspect in the codified conflict of Hindu religion, Indian tradition and modernity, as Srivasta points out: The idea of an , unified nation consisting of the construct of public ceremonies, symbols, institutions and discourses is of recent origin. It is paradoxical ... that traditions are used to justify the current social arrangements of a modern nation (Srivastava 2002).

One of the strategies employed by Hindi filmmakers to reduce the chances of box-office failure is to remake or adapt Hollywood, Telugu, Tamil, and older Hindi films. Bombay filmmakers regard box-office successes or "hits" in other Indian languages as attractive remake material because, having already succeeded with a set of audiences, such films are perceived as having a higher probability of succeeding with Hindi film audiences as well. Hollywood films, however, are not selected only on the basis of box-office outcome but are chosen for plots that seem novel and amenable to adaptation. Although remakes from other Indian languages resemble the original screenplay, adaptations of Hollywood films barely do because they have been transformed—or "Indianized," in industry parlance—-to conform with the conventions of Hindi cinema. 


\section{Culture and Media}

Although Bombay filmmakers have been adapting Hollywood films for decades, the media landscape in which they operate has changed considerably since the entry of satellite and cable television in 1991, with the resulting increase in the number of television channels available locally, regionally, and nationally. Filmmakers explain that because they are competing with television for audiences they must create a cinematic experience extraordinary enough to seduce audiences away from their television sets at home and into theatres, and Hindi film production since the mid-1990s has been marked by vastly improved production values, increased spectacle, foreign locales, slick marketing, and subsequently higher costs. The presence of satellite channels such as Star Movies and TNT that broadcast feature films also means that some portion of the audience has access to the Hollywood films that are the sources for adaptations.

Unlike recent work on cinematic remakes (Horton and McDougal 1998) and cross-cultural adaptations (Horton 1998; Aufderheide 1998; Nayar 1997), which are primarily concerned with questions of narrative, genre, and intertextuality, Indianization can also be examined as not a relationship between texts but as a relationship between filmmakers and audiences. Much of the ethnographic research about the mass media has centred on television audiences and the moment of reception. However, as Ang (1991) and Dornfeld (1998) have argued, the idea of the audience must also be located in the production process. Whereas other scholars have examined Indianization with the purpose of delimiting what is uniquely "Indian" about the codes and conventions of mainstream Hindi cinema (Thomas 1985, 1995; Nayar 1997), Indianization can also be outlined as a practice that allows one to see how Hindi filmmakers think about and construct their audiences. Not every Hollywood film is capable of being "Indianized," however, and as the opening anecdote indicates, sometimes after watching a particular film closely the director decides that the film is unsuitable for adaptation. Unlike other methods, an ethnographic focus on media production provides access to these "negative" instances or episodes in which films get rejected in the conceptualization stage. Such moments of inchoate production reveal how Hindi filmmakers operate as cultural mediators, evaluating the appropriateness for their audiences of stories, characterizations, and themes from certain Hollywood films. Hindi

filmmakers frequently elaborate the difference between their films and Hollywood films in a language of constraints and compulsions as mediated through the figure of "the audience." What becomes apparent during the processes of selection and adaptation is filmmakers' ambivalence toward their audiences. Rather than "indigenizing" or domesticating difference (Tobin 1992), Indianization is a practice of constituting difference-between India and the West, and more important, between filmmakers and audiences.

Throughout the filmmaking process, Hindi filmmakers justify their narrative, dramatic, and aesthetic choices according to what they believe audiences will accept and reject. In the process of trying to produce a "hit," filmmakers theorize about audiences' motivations for seeing a film and how they derive pleasure from it. Rather than relying on any formal market research, their claims about audience tastes and preferences are based on a mix of intuition, observation of box-

(c) The International Journal of Indian Psychology, ISSN 2348-5396 (e)| ISSN: 2349-3429 (p) | 205 


\section{Culture and Media}

office successes and failures, and first-hand viewing of films in theatres with audiences. Deciding which film is suitable for adaptation involves a complex amalgam of factors such as filmmakers' interpretations of films, their own film-viewing experiences, their assessment of a film's novelty, loyalty to the narrative conventions of Hindi cinema, and filmmakers' assumptions about their audiences.

\section{Present study}

The present study is a comparison between movieswhose remake has been made in a different cultural context to study how movies are a reflection of culture. The movie selected for the purpose was Hollywood movie; Harry met sally and its Bollywood remake, Hum tum. The cultural differences in terms of values, norms, attitudes, situations, language, art, and literature, marriage, relationships and religion were analysed between these two movies.

Research question: Do movies reflect the culture where they are produced?

\section{Objective:}

- To understand the differences and similarities between a movie and its cross-cultural remake on the basis of culture.

\section{METHOD}

The method used to study the comparison between the movies was theory driven content analysis, which use a subject-specific theory to inform their qualitative analysis. Content analysis describes a family of analytic approaches ranging from impressionistic, intuitive, interpretive analyses to systematic, strict textual analyses (Rosengren, 1981). The specific type of content analysis approach chosen by a researcher varies with the theoretical and substantive interests of the researcher and the problem being studied (Weber, 1990). The differentiation of content analysis is usually limited to classifying it as primarily a qualitative versus quantitative research method. A more thorough analysis of the ways in which qualitative content analysis can be used would potentially illuminate key issues for researchers to consider in the design of studies purporting to use content analysis and the analytic procedures employed in such studies, thus avoiding a muddling of methods (Morse, 1991).

The primary drawback to content analysis is that context is usually not considered or is highly constrained, limiting the richness of the summary data produced. Thematic analysis, in contrast, is more involved and nuanced. Thematic analysis moves beyond counting explicit words or phrases and focuses on identifying and describing both implicit and explicit ideas. Codes developed for ideas or themes are then applied or linked to raw data as summary markers for later analysis, which may include comparing the relative frequencies of themes or topics within a data set, looking for code co-occurrence, or graphically displaying code relationships. 


\section{Culture and Media}

Both content and thematic analysis can be data-driven, as in grounded theory (Glaser and Strauss 1967, Kearney et al. 1994, Wright 1997), or theory-driven (Krippendorf 1980, Weber 1990). In a data-driven approach, the researcher carefully reads and rereads the data, looking for keywords, trends, themes, or ideas in the data that will help outline the analysis, before any analysis takes

place. By contrast, a theory-driven approach is guided by specific ideas or hypotheses the researcher wants to assess. The researcher may still closely read the data prior to analysis, but his or her analysis categories have been determined a priori, without consideration of the data. Thus, theory driven content analysis was used as no previous themes were decided beforehand and the movies were analysed on the basis of cultural elements shown in both movies.

\section{Data}

Plot of movie Hum Tum and Harry met Sally

Hum Tum follows the encounters of the two main characters until they, after several years and various meetings, become friends and finally fall in love at the end of the movie. The comic characters Hum and Tum have their own animated sequences in the movie, where they represent the current state of Karan's and Rhea's relationship.

Harry and Sally first meet as they finish college in Chicago and spend 18 hours together in a car headed to New York. They don't quite hit off, particularly after Harry opines that a man and a woman can never be just friends because he'll always want to have sex with her. Over the next 10 years, they occasionally meet and soon do in fact become fast friends. They share the intimate details of their lives - hopes, dreams, failures and successes - and in the process also fall in love. It's not evident that will be able to sustain their relationship once they sleep together however.

\section{SUMMARY OF THESE MOVIES}

\section{Hum Tum}

Karan in the movie hum tum is the lead actor and is a cartoonist and a self-styled ladies' man. His daily comic, named "Hum Tum," explores the battle of stereotypical male/female behaviour. On a plane from Delhi to New York, he meets Rhea, the leading lady in the movie, who is represented by Rani Mukeerji, who doesn't seem to be interested in him. They both agree to explore the city Ambestdom together. Karan quickly learns he has little in common with Rhea, but he doesn't give up his flirting and chance. He ends their contentious time together with an unwelcome kiss. Outraged, Rhea slaps him, and storms off, but Karan insists they'll meet again. After a few months he spots her in a park in New York, and she makes a scene with his girlfriend who turns out to be Rhea's childhood friend, which ends in their break-up.

Three years later, when Karan is helping his mother plan a wedding that turns out to be Rhea's. Rhea is marrying Sameer, represented by Abhishek Bachan. They bicker again, but this time, they part on good terms. Years later in when in Paris Karan is visiting his father, he runs into Rhea. He learns from Rhea's mother that Sameer has died in a car accident, and he sets out to help her reclaim her positive outlook on life. Karan returns to Mumbai, and three months later,

(C) The International Journal of Indian Psychology, ISSN 2348-5396 (e) | ISSN: 2349-3429 (p) | 207 


\section{Culture and Media}

Rhea and her mother visit. Sensing that she needs to be with a strait-laced guy he conspires with Rhea's mother to fix her up with his shy best friend, Mihir. But eventually Mihir falls in love with a friend of Karan's, Diana and they get engaged. On the engagement night Rhea learns from drunk Diana about the conspiracy, and gets upset with Karan. Mihir makes Rhea realize hers and Karan's love for each other. That night Rhea and Karan consummate their relationship. Karan deems it a mistake and asks Rhea to marry him as he feels he took advantage of her, and that marriage will rectify the mistake. Rhea becomes upset, as she did not consider their actions a mistake; she realizes she loves him but tells Karan that they should not commit one more mistake by marrying for the wrong reasons. Rhea leaves him since Karan projects his confused feelings as guilt rather than as love for her. Karan realises his mistake, and goes out to find her. One year later Karan's cartoon Hum Tum becomes a hit and he writes a book about Hum and Tum. Basically the story is based on his love story with Rhea. Rhea reads that book and finds him in the press conference. Karan and Rhea reunite again. Karan admits his love for her, and they get married and have a baby girl.

\section{When Harry met sally}

Harry Burns and Sally Albright graduate together from the University of Chicago and share the drive to New York City, where Sally is beginning Journalism school and Harry is starting a career; at the time, Harry is dating a friend of Sally's, Amanda. During the drive, they discuss their differing ideas about relationships between men and women. Harry says that "Men and women can't be friends because the sex part always gets in the way". Sally disagrees, claiming that men and women can be strictly friends without sex. During a stop in a diner, Sally is angered when Harry tells her she is attractive; she accuses him of making a pass at her. In New York, because of their divergent philosophies, they part on unfriendly terms.

Five years later, they meet in a New York airport and find themselves on the same plane. Both are in relationships; Sally has just started dating a man named Joe, who turns out to be neighbour of Harry's and Harry is engaged to a woman named Helen, which surprises Sally. Harry suggests they become friends, forcing him to elaborate on his previous rule about the impossibility of male-female friendships. Despite Harry's suggestions of exceptions to that rule, they eventually separate, concluding that they will not be friends.

Harry and Sally run into each other again five years later, in a New York bookstore. They have coffee and talk about their previous relationships, both of which have ended, with Sally and Joe breaking up because she realized she wanted a family and he didn't want to get married, and Harry's because Helen fell in love with another man. After leaving the café, they take a walk and decide to be friends. In subsequent scenes, they have late-night phone conversations, go to dinner, and spend a lot of time together. Their dating experiences with others continue to highlight their different approaches to relationships and sex.

(C) The International Journal of Indian Psychology, ISSN 2348-5396 (e) | ISSN: 2349-3429 (p) | 208 


\section{Culture and Media}

During a New Year's Eve party, Harry and Sally find themselves attracted to each other. Though they remain friends, they set each other up with their respective best friends, Marie and Jess. The four go to a restaurant, where Marie and Jess hit it off and later become engaged. One night, over the phone, Sally tearfully tells Harry that her ex is going to marry. He rushes to her apartment to comfort her, and they unexpectedly have sex, resulting in an awkward moment the next morning as Harry quickly leaves in a state of distress. This creates tension in their relationship. Their friendship cools for three weeks until the two have a heated argument during Jess and Marie's wedding dinner. Following this fight, Harry repeatedly attempts to mend his friendship with Sally, but she feels that they cannot be friends after what happened.

Then, at a New Year's Eve party that year, Sally feels alone without Harry by her side. Meanwhile, Harry is shown spending New Year's alone as he walks around the city. As she decides to leave the party early, Harry appears and declares his love for her. At first she argues that the only reason he is there is because he is lonely, but he disagrees and lists the many things he realized he loves about her. They make up and kiss, and in a short closing scene after that shows them being interviewed together, they say that they married three months after that night.

\section{RESULT}

Table1: The table shows the differences observed in the cultural context of these two movies.

\begin{tabular}{|c|c|c|}
\hline $\begin{array}{ll}\text { Elements } & \text { of } \\
\text { culture/codes } & \end{array}$ & Harry met sally & Hum Tum \\
\hline $\begin{array}{l}\text { Attitudes } \\
\text { values }\end{array}$ & $\begin{array}{l}\text { When Rhea and Karan consummate } \\
\text { their relationship, it is shown with the } \\
\text { feelings of guilt. }\end{array}$ & $\begin{array}{l}\text { In the movie Harry met Sally, } \\
\text { when they unexpectedly have } \\
\text { sex, creates tension in their } \\
\text { relationship. But here the } \\
\text { characters are not shown } \\
\text { witnessing guilt. }\end{array}$ \\
\hline Family & $\begin{array}{l}\text { Family plays an important support } \\
\text { system and play's major role in } \\
\text { decision making. } \\
\text { Here, Karan's phobia of being } \\
\text { committed is also shown to be } \\
\text { influenced by the separation of his } \\
\text { mom and dad. }\end{array}$ & $\begin{array}{l}\text { Family is not depicted in the } \\
\text { movie }\end{array}$ \\
\hline Songs and music & $\begin{array}{l}\text { Songs were used to convey emotions, } \\
\text { feelings and love. }\end{array}$ & No songs were used in the movie \\
\hline $\begin{array}{l}\text { Gender } \\
\text { stereotyping }\end{array}$ & $\begin{array}{l}\text { The songs used in the movie manifests } \\
\text { stereotypical behaviour between the } \\
\text { men and women. } \\
\text { It is also shown through the cartoons }\end{array}$ & $\begin{array}{l}\text { No stereotypical gender } \\
\text { stereotyping was shown in the } \\
\text { movie. }\end{array}$ \\
\hline
\end{tabular}

(C) The International Journal of Indian Psychology, ISSN 2348-5396 (e) | ISSN: 2349-3429 (p) | 209 


\section{Culture and Media}

\begin{tabular}{|c|c|c|}
\hline Elements of & Harry met sally & Hum Tum \\
\hline & $\begin{array}{l}\text { of Hum Tum, which gives } \\
\text { stereotypical behaviour to girls and } \\
\text { boys. } \\
\text { When the two characters were } \\
\text { showing drinking, these were again } \\
\text { highlighted. }\end{array}$ & \\
\hline Belief system & $\begin{array}{l}\text { In the movie, It is shown that Rhea's } \\
\text { husband has died and they both are } \\
\text { shown becoming good friends. } \\
\text { Divorce is shown not acceptable and } \\
\text { the separation of Karan's parents is } \\
\text { shown to negatively affect Karan's } \\
\text { growth. }\end{array}$ & $\begin{array}{l}\text { In Harry met Sally, when Harry } \\
\text { and Sally run into each other } \\
\text { again after five years it is shown } \\
\text { that both had broken up their } \\
\text { previous relationships. } \\
\text { Divorce is shown acceptable. }\end{array}$ \\
\hline
\end{tabular}

Table 2: It shows the similarities observed in the two movies.

\begin{tabular}{|l|l|l|}
\hline $\begin{array}{l}\text { Elements } \\
\text { culture/codes }\end{array}$ & Harry met sally & Hum Tum \\
\hline Friends & $\begin{array}{l}\text { Both try to set each other against their } \\
\text { friends, but both their friends end up } \\
\text { dating each other. }\end{array}$ & $\begin{array}{l}\text { The friend, Karan wanted to set } \\
\text { Rhea with falls for his date, } \\
\text { Diana. }\end{array}$ \\
\hline
\end{tabular}

\section{DISCUSSION}

Culture as a complex whole which includes knowledge, belief, art, morals, law, custom and any other capabilities and habits acquired by man as a member of society. Cambridge English Dictionary states that culture is, "the way of life, especially the general customs and beliefs, of a particular group of people at a particular time. Taylor (2005)

Popular culture influences the media to some extent, but the media influence popular culture as well. The media influence popular culture by helping to spread that culture around. People read about or see culture type things in the media and learn about them in that way. Culture also affects the media, though. The media has to adapt to what people are used to. We can see this in how the mainstream media has to react to what is being said on blogs and on websites and such. One aspect of cross-cultural exchange is the film remake - a film based on another film. The cinematic remaking of other films has a long history and cinemas around the world have continually remade other nations' films (Forrest and Koos, 2002). Every cinema reflects the culture of which it belongs, and a nation's cultural conventions, traditions, and expectations will affect the remake in significant ways. The remake is a common and important form of cultural borrowing and expression in a globalized world. For the present study, a comparison between

(C) The International Journal of Indian Psychology, ISSN 2348-5396 (e)| ISSN: 2349-3429 (p) | 210 


\section{Culture and Media}

movies whose remake has been made in a different cultural context was selected. The movie selected for the purpose was Hollywood movie; Harry met sally and its Bollywood remake, Hum tum. The cultural differences in terms of values, norms, attitudes, situations, language, art, and literature, marriage, relationships and religion were analysed between these two movies.

Both Hum Tum and Harry met Sally follows the encounters of the two main characters until they, after several years and various meetings, become friends and finally fall in love at the end of the movie. In Harry and Sally the two main characters Harry and Sally, first meet as they finish college in Chicago and spend 18 hours together in a car headed to New York. They don't quite hit off, particularly after Harry opines that a man and a woman can never be just friends because he'll always want to have sex with her. Over the next 10 years, they occasionally meet and soon do in fact become fast friends. They share the intimate details of their lives - hopes, dreams, failures and successes - and in the process also fall in love. While Hum Tum follows the same pattern where the two main characters meet at different times and fight, become friends and ultimately fall in love. The portrayal of relationships between the characters in the film particularly that of the main lead, Karan and Riya, is handled with comedy and emotional drama. There are some similarities in the general concept of plot but both have pretty much own story which depends upon their different cultural contexts.

\section{Attitudes, Values And Social Norms:}

The differences in the movie can be attributed to different elements of culture. In both the movies eventually the characters are shown to fall in love but the endings are very different and can be seen in the context of prevailing cultural, religious and social norms. In the movie Hum Tum, the night when Rhea and Karan consummate their relationship, Karan deems it a mistake and asks Rhea to marry him as he feels he took advantage of her, and that marriage will rectify the mistake. In this sense marriage is seen as an important part of Indian culture and having sex before marriage seems to threaten the cultural norms. Rhea leaves him since Karan projects his confused feelings as guilt rather than as love for her. Karan realises his mistake, and goes out to find her. The movie ends when Karan admits his love for her, and they get married and have a baby girl. This can be seen as an Indianization technique where Hindi filmmakers think about and construct the movie according to what is acceptable to their audiences according to the prevailing norms and traditions.

While in the movie Harry met Sally, when they unexpectedly have sex, resulting in an awkward moment the next morning as Harry quickly leaves in a state of distress. This creates tension in their relationship. Their friendship cools for three weeks until the two have a heated argument during Jess and Marie's wedding dinner. Following this fight, Harry repeatedly attempts to mend his friendship with Sally, but she feels that they cannot be friends after what happened. Here, the characters were not shown as having guilt unlike in movie Hum Tum, rather were worried what the other person might be thinking as it happened during the course of 'friendship'. In the end 


\section{Culture and Media}

they make up and kiss, and in a short closing scene after that shows them being interviewed together, they say that they married three months after that night. The kissing scene is frequently shown in the Hollywood movie but is missing in the Hum Tum, also the feelings both couples go through and how they deal with it after consummating their relationship is different and can be attributed to the attitudes and values their respective cultures attach to it.

\section{Family:}

The second major difference can be seen is the values attach to relationships. In harry met sally, there is no mention of the characters family but in the movie hum tum, a collectivistic culture is being shown, where the presence of Rhea's mother and Karan's father and mother is used as an important part of story. As shown when Karan is visiting his father, he runs into Rhea. He learns from Rhea's mother that Sameer has died in a car accident, and he sets out to help her reclaim her positive outlook on life. This difference throws light on the attribution of Indian culture, which places a lot emphasis on family. A study done by Warson (2002) shows that Indians are part of collectivistic culture where the right of family, community and society supersedes that of individual. While US represents an individualistic pattern of culture where feelings of autonomy and interdependence are valued over harmony and interdependence.

Therefore, family is the most important social unit, where people live under a clear order of social precedence based on gender and age, where the senior male is the family head. Indian culture is therefore patriarchal, where arranged marriages are common. The high versus low culture that we find in Edensor and Hall is though not applicable in India, as films are cultural forms that are both seen as entertainment and art.

\section{Belief system:}

Another major difference between the two movies can be attributed to different belief system prevailing in their societies. In both the movies it is shown that the two characters meet on different occasions and time and evolve their relationship from bickering and fighting to friendship and then to love. In the movie Hum Tum, when the characters runs into each other after few years in Paris, Karan learns that Rhea's husband has died and they both are shown becoming good friends. While in the movie Harry met Sally, when Harry and Sally run into each other again after five years in a New York bookstore. They both have coffee and learn about each other's previous relationships, both of which have ended, with Sally and Joe breaking up and Harry and Helen parting as Helen fell in love with another man. Both the movies are trying to show that after few years the two characters have met and developed friendship but in very different contexts. While in Hollywood movie a previous breakup shown of the two main characters falls within their belief system as dating is very common and acceptable there but when the filmmakers adapted it in Bollywood, they altered the breakup part by showing a previous marriage of the lady which evokes the sympathy of the guy as her husband has died. This can be attributed to the belief in India that marriage is sacrosanct and a taboo is placed on 


\section{Culture and Media}

divorce and breakup of a woman, so it is conveniently shown that she is single again as a result of death of her spouse.

Also, in the movie harry met sally, it is shown that Helen (Harry's wife) fell in love with another man and they divorced. In conservative countries, like India, divorce is still a taboo. Religious laws might make divorce far more complicated and harder to attain. Western nations in general have smoother legal systems when it comes to divorce. Again, US rank at the top of the West as it is a much more litigious society than most. All these reasons are a result why the two movies adapted different styles to suit their cultural audience.

\section{Songs and Music:}

It's not only the stories but the music which also exhibit cultural differences. In the Bollywood movie, the songs are integral part of Indian weddings, festivals or the parties. Not just in celebration but also in the lonely nights at rooftops with radio. Moreover, it was the films that spread fashion and cosmopolitan Bombay's trends to the towns and cities of India. So when Harry met Sally was adapted to suit Indian audiences, lot of music, wedding songs were added. Some of the many films that have been remade and thereby Indianized, are Dead Poets Society (Weir, 1989) into Mohabbatein (Chopra, 2000), and Three Men and a Baby (1987) into HeyyBabyy (Khan, 2007. Common for all these films is the adding of content, Indian morality, stronger emotions - in particular love, and the song and dance sequences, making them suitable for India, Bollywood, and its audience. Also, the songs in the movie Hum Tum goes on to promote the stereotypical behaviour of men and women.

\section{Gender stereotyping:}

The songs that were used in the movie Hum Tum reinforced the gender stereotypical behaviour between men and women. In the song: 'Na jaane kyon ladkiyan, ladkonsi nahi hoti' which promotes social roles associated with women and men, where women are supposed to be fragile and seek protection, men are supposed to be one step ahead of women. It is conversation song between a girl and a boy who are trying to establish their supremacy over one another; it is a ched-chaad song. In another instance, when Karan gets to know that Rhea's husband has died, he tries to set her up with another 'decent' guy. This again is manifestation of stereotypical gender norms of Indian society, where a 'decent' guy is one who never hooks up other women. This can be attributed to the prevailing social norms and customs of the Indian society.

When dealing with cross-cultural remakes one is dealing with cultural adaptation, as one can analyse film remakes not only in their textual and structural specificity, but in a wider cultural context. The cultural analysis includes the filmic and cultural element changes accompanying this process of remaking from the American culture seen through Hollywood, with the culture of India presented through Bollywood cinema. The changes include adjusting the story to fit with 


\section{Culture and Media}

the classical rules of the genre story-telling worked out in America, and the cinematic formula of Hindi Cinema.

\section{Similarities}

In both the movies the role and presence of friends are shown. In the movie Hum tum, Karan conspires with Rhea's mother to fix her up with his shy best friend, Mihir. But eventually Mihir falls in love with a friend of Karan's, Diana and they get engaged. Similarly in the movie, Harry met sally, they set each other up with their respective best friends, Marie and Jess. The four go to a restaurant, where Marie and Jess hit it off and later become engaged. This similarity between the two movies can be attributed to the value attached with friends in both cultures. In collectivistic culture like India, friends play an important supportive role, therefore, it can be concluded that the filmmakers found it to be appropriate and retained it in Bollywood.

\section{CONCLUSION}

For the present study, a comparison between movies whose remake has been made in a different cultural context was selected. The movie selected for the purpose was Hollywood movie; Harry met sally and its Bollywood remake, Hum tum. The differences observed in the two movies can be attributed to existing cultural dynamics prevailing in these countries. These were analysed through theory based content analysis. Differences were found in the attitudes, values, stereotypes, music, food, belief system and cultural norms. Similarities were found in context of friends, which shows the value both cultures attach with them. It can be said that Bollywood filmmakers operate as cultural mediators, evaluating the appropriateness of a film according to their perception of the audience, and this Indianization continues to be a conservative process as it stays the same and keeps the risks low. Every cinema reflects the culture of which it belongs, and a nation's cultural conventions, traditions, and expectations will affect the remake in significant ways. Thus, a movie is a common and important form of cultural expression.

\section{Acknowledgments}

The author appreciates all those who participated in the study and helped to facilitate the research process.

\section{Conflict of Interests}

The author declared no conflict of interests.

\section{REFERENCES}

Adorno, Theodor. 1976. Introduction to the Sociology of remix. New York: Seabury.

Anantharaman, Ganesh. Bollywood Melodies: A History of the Hindi Film Song. India: Penguin Books. 2008.

Bakshi, Kapoor, R. 2002. JisDesh Mein Ganga BehtiHai to Ram Teri Ganga Maili: The Secret Politics of Our Desires: Innocence, Culpability and Indian Popular Cinema. 


\section{Culture and Media}

Bhattacharya, Mehta. 2010. Bombay to Bollywood: Tracking Cinematic Tours. Global Bollywood: Travels of Hindi Song and Dances. University of Minneapolis.

Bollywood and Hollywood remix: Rediff.com. Retrieved 2016-03-16.

Booth, Gregory.D.1995. Traditional Content and Narrative Structure in the Hindi Commercial Cinema. Asian Folklore Studies, 169-190.

Brown, Steven R. 1996. Quantitative Methodology and Qualitative Research. Qualitative Health Research.561-568.

Jump up to: Hum tum and Harry met sally: Rotten Tomatoes. Retrieved 2016-03-15.

Khan and Debroy. 2008. Indianisation techniques used in Bollywood: Bollywoodkhabar.com. Retrieved on 2016-04-18

P. Sagik. 2001.Cultural Psychology: Pearson: University of Toronto.

Rosengren, K. E. (1981). Advances in Scandinavia content analysis: An introduction. In K. E. Rosengren (Ed.), Advances in content analysis (pp. 9-19). Beverly Hills, CA: Sage

Tesch, R. (1990). Qualitative research: Analysis types and software tools. Bristol, PA: Falmer. Vincent, J.-L.(1997). Communication in the ICU. Intensive Care Medicine, 23, 1093-1098.

How to cite this article: K Kaur (2016), Culture and Media, International Journal of Indian Psychology, Volume 3, Issue 4, No. 56, ISSN 2348-5396 (e), ISSN: 2349-3429 (p), DIP: 18.01.020/20160304, ISBN: 978-1-365-23992-2 